\title{
Interpretasi Sistem Digitalisasi Legalitas Dan Administrasi UMKM
}

\author{
Yuni Ekawarti ${ }^{1}$, Triana Agustini ${ }^{2}$ dan Widarti ${ }^{3}$ \\ ${ }^{1}$ Akuntansi Universitas Tamansiswa Palembang, Indonesia \\ ${ }^{2}$ Manajemen Universitas Tamansiswa Palembang, Indonesia \\ ${ }^{3}$ Akuntansi Universitas Tamansiswa Palembang, Indonesia \\ Email korepondensi: yuni@unitasplg.ac.id
}

\begin{abstract}
ABSTRAK
Era industri 4.0 yang mensyaratkan ketersediaan teknologi digital untuk mendukung aktivitas ekonomi termasuk dalam pengembangan UMKM. Terlebih lagi dimasa pandemic COVID-19. Fungsi dari digitalisasi pada sebagian besar UMKM sangat diperlukan. Penelitian ini bertujuan untuk mengetahui seberapa besar pemahaman pelaku UMKM terutama di Kec.Talang Kelapa terhadap Digitalisasi UMKM terutama pada sektor legalitas dengan menggunakan OSS (One Single Submission) atau perijinan satu atap via online dan pemahaman pencatatan keuangan dengan akuntansi. Metode penelitian yang digunakan adalah dokumentasi dan wawancara dengan penyebaran kuesioner yang diberikan kepada 50 UMKM di Kec. Talang Kelapa,. Hasil penelitian menunjukkan bahwa 46\% UMKM belum mempunyai legalitas usaha, dan hanya $26 \%$ yang mempunyai legalitas diurus secara online, sementara 74\% UMKM belum mampu memisahkan pembukuan pribadi dan usaha serta belum mampu mengoperasikan software pembukuan sederhana untuk UMKM.
\end{abstract}

Kata kunci: UMKM, Digital, Legalitas, Akuntansi

\section{PENDAHULUAN}

Indonesia merupakan negara berkembang yang menitikberatkan pertumbuhan ekonomi dan pembangunan ke arah yang lebih baik. Ini sudah dimulai dengan adanya bentuk usaha-usaha berskala besar maupun kecil yang amat beragam. Salah satu jenis usaha yang terdapat di Indonesia yaitu Usaha Mikro, Kecil dan Menengah (UMKM). Bidang usaha yang salah satunya dapat berkembang dalam perekonomian nasional yaitu UMKM. UMKM merupakan sebuah tempat yang baik bagi penciptaan lapangan pekerjaan dan pertumbuhan ekonomi. Internet memudahkan segala aspek kehidupan mulai dari pendidikan hiburan, informasi, pelayan publik, pengetahuan, iklan, investasi, interaksi atau komunikasi, serta bisnis dan berjualan. Adanya internet inilah diharapkan menjadi instrumen pendukung dan penguat para pelaku ekonomi kreatif dan UMKM dalam mengembangkan bisnis dan memasarkan jualannya. Dengan semakin banyaknya usaha kecil dan menengah yang terlibat dalam ekonomi digital melalui broadband, e-commerce, media sosial, cloud, dan mobile platforms, UKM dapat bertumbuh lebih cepat dari segi pendapatan dan penyediaan lapangan kerja, serta menjadi lebih inovatif dan lebih kompetitif untuk menghadapi Masyarakat Ekonomi ASEAN(Agustin et al., n.d.)(Rofiah, 2020).

Digitalisasi ini merupakan sarana yang telah difasilitasi oleh Negara melalui pengesahan beberapa Peraturan Perundang-Undangan. Di era digital saat ini, bentuk UMKM tidak terbatas pada toko secara fisik (offline) saja, tetapi para pelaku usaha sudah memasuki ranah pemasaran secara online. Toko offline maupun online dalam memasarkan produknya, UMKM tetap harus memiliki izin usaha atau legal usaha dan ini seringkali diabaikan oleh para pelaku UMKM (Suhardiyah et al., 2020). Bagi para pengusaha yang baru saja memulai usaha, sangat penting untuk memiliki merek usaha dan izin yang terdaftar agar menghindari orang lain menggunakan 
merek dan izin usaha tersebut (Yohanna et al., 2016) Legalitas juga memiliki peran yang sangat penting untuk membantu UMKM dimasa pandemi covid-19. Melalui legalitas yang lengkap, UMKM dapat mengajukan berbagai bantuan yang telah disediakan oleh pemerintah.

Pemerintah Indonesia berupaya meningkatkan efisiensi kegiatan usaha dengan percepatan pelaksanaan berusaha yang disusun dalam Peraturan Pemerintah Nomor 24 Tahun 2018 tentang Pelayanan Perizinan Berusaha Terintegrasi Secara Elektronik. Berdasarkan kebijakan tersebut, semua pelayanan perizinan usaha menjadi terintegrasi oleh pusat melalui 1 (satu) Sistem Perizinan Berusaha Secara Elektronik Online Single Submission (OSS). Namun dibalik itu semua, terdapat kendala atau tantangan yang dihadapi pelaku UMKM yaitu terkait dengan pengolahan dana dan penyusunan laporan keuangannya karena pengolahan dana yang baik akan menjadi faktor penting dalam keberhasilan UMKM itu sendiri (Agustin et al., n.d.) . Menurut Agustin (2019) berpendapat bahwa kelemahan UMKM dalam penyusunan laporan keuangan disebabkan rendahnya pendidikan, kurangnya pemahaman terhadap Standar Akuntansi Keuangan (SAK), dan pelatihan penyusunan laporan keuangan. Selain itu bagi pelaku UMKM, keterbatasan pengetahuan pembukuan akuntansi, rumitnya proses akuntansi, dan anggapan bahwa laporan keuangan bukanlah hal yang penting bagi UMKM.

Berdasarkan permasalahan di atas, peneliti merasa tertarik untuk mengkaji permasalahan tersebut dan mencari alternative pemecahannya yang dituangkan dalam usulan penelitian yang berjudul "Interpretasi Sistem Digitalisasi Legalitas dan Akuntansi UMKM di Kec. Talang Kelapa"

Adapun tujuan dari penelitian ini untuk mengetahui bagaimana aplikasi pelaksanaan sistem perijinan online diterapkan oleh pelaku UMKM di Kec. Talang Kelapa, mengetahui bagaimana penerapan sistem pencatatan Akuntansi oleh pelaku UMKM di Kec. Talang Kelapa.

\section{KAJIAN PUSTAKA}

\section{UMKM (Usaha Mikro Kecil Menengah)}

Usaha Mikro, Kecil, dan Menengah (UMKM) memiliki definisi yang berbeda pada setiap literatur menurut beberapa instansi atau lembaga bahkan undang-undang. Sesuai dengan Undang-undang Nomor 20 Tahun 2008 (UU No. 20 Tahun 2008, 2008) tentang Usaha Mikro, Kecil, dan Menengah didefinisikan sebagai berikut:

a) Usaha mikro adalah usaha produktif milik orang perorangan dan/atau badan yang memenuhi kriteria usaha mikro (aset maksimal 50 juta dan omset 300 juta) sebagaimana diatur dalam Undang-Undang ini.

b) Usaha Kecil adalah usaha ekonomi produktif yang berdiri sendiri, yang dilakukan oleh orang perorangan atau badan usaha yang bukan merupakan anak perusahaan atau bukan cabang perusahaan yang dimiliki, dikuasai, atau menjadi bagian baik langsung maupun tidak langsung dari Usaha Menengah atau Usaha Besar yang memenuhi kriteria Usaha Kecil sebagaimana dimaksud dalam Undang-Undang ini. Kriteria Omzet lebih dari Rp. 50.000.000,00 sampai Rp. 500.000.000,00.

c) Usaha Menengah adalah usaha ekonomi produktif yang berdiri sendiri, yang dilakukan oleh orang perorangan atau badan usaha yang bukan merupakan anak perusahaan atau cabang perusahaan yang dimiliki, dikuasai, ataupun menjadi bagian baik langsung maupun tidak langsung dengan Usaha Kecil atau Usaha Besar dengan jumlah kekayaan bersih atau hasil penjualan tahunan sebagaimana diatur dalam Undang-Undang ini. Kriteria Omzet lebih dari Rp. 500.000.000,00 sampai Rp. 10.000.000.000,00.

Pada Tahun 2017, tercatat bahwa 60,34\% kontribusi produk domestik bruto (PDB) di Indonesia disumbang oleh Usaha Mikro Kecil (UMK), sedangkan untuk tahun 2018 tercatat bahwa UMKM di Indonesia menyerap 116,9 juta tenaga kerja atau berarti 97\% total tenaga 
kerja di Indonesia diserap oleh sektor UMKM. Hal ini membuktikan bahwa UMKM sangat efektif dalam mengurangi jumlah pengangguran di Indonesia (Thaha, 2020). Untuk itu sangat penting bagi pemerintah mendukung UMKM untuk terus maju dan berkembang.

\section{Digitalisasi Legalitas}

Legalitas juga memiliki peran yang sangat penting untuk membantu UMKM dimasa pandemi covid-19. Melalui legalitas yang lengkap, UMKM dapat mengajukan berbagai bantuan yang telah disediakan oleh pemerintah. Adapun bantuan pemerintah dimasa covid ialah dengan menerapkan berbagai program bantuan sosial seperti peningkatan jumlah penerima bantuan pada program keluarga harapan (Pramanik, 2020) (Pramanik, 2020).Akses bantuan pemerintah seperti ini tentu saja hanya berlaku untuk usaha mikro yang memiliki legalitas atau perizinan usaha yang lengkap.

Kemudahan akses dalam mendapatkan izin usaha melalui sistem OSS dapat menjadi solusi legalitas bagi UMKM, karena sampai saat ini masih banyak pelaku usaha diIndonesia yang tidak memiliki legalitas usaha. Hal ini salah satunya terjadi akibat ketidaktahuan para pengusaha dalam mengakses izin usaha tersebut (Gultom, 2020).Online single submission (OSS) adalah sistem website yang sangat bermanfaat untuk memfasilitasi perizinan dan pengaduan agar nantinya para pengambil keputusan dapat melakukan kegiatan penindakan. Ada banyak hal baru yang disediakan oleh OSS seperti syarat yang seragam melalui automatic approval menu dan yang penting juga, proses OSS sangat cepat karena dokumen tidak melewati proses pengecekan yang lama dan ribet. Selagi dokumen yang diajukan telah sesuai dengan syarat yang diminta oleh sistem, maka izin usaha bisa didapatkan (Arrum, 2019) .

\section{Akuntansi UMKM}

Masyarakat memiliki hambatan dalam mengakses lembaga keuangan. Tingginya unbankable people disebabkan karena gap kemiskinan antar provinsi, rendahnya pembiayaan UMKM, suku bunga kredit mikro tinggi, asymmetric information, kemampuan manajemen UMKM kurang memadai, monopoli bank pada sektor mikro, dan terbatasnya saluran distribusi jasa keuangan. Otoritas Jasa Keuangan (2016), menjelaskan bahwa peningkatan literasi dan inklusi keuangan diyakini bisa mengembangkan Usaha Mikro Kecil dan Menengah (UMKM) karena pelaku UMKM dapat lebih memahami konsep dasar dari produk keuangan, melakukan perencanaan dan pengelolaan keuangan yang lebih baik, serta melindungi mereka dari penipuan dan usaha tidak sehat di pasar keuangan. Pengetahuan akuntansi memiliki andil besar dalam kemajuan usaha yang dikelola, pengetahuan akuntansi yang rendah akan menyebabkan usaha yang dijalankan mengalami kegagalan manajemen sehingga sulit bagi pelaku usaha dalam menentukan kebijakan apa yang akan diambil (Hudha, 2017) .

Menurut (Hudha, 2017), pengetahuan akuntansi yang dimiliki oleh pelaku UMKM mempengaruhi penggunaan informasi akuntansi yang ada. Namun demikian sebagian UMKM masih merasa bahwa usaha yang dimiliki masih kecil dan banyak tingkat kerumitan yang masih menjadi alasan untuk tidak melakukan pengelolaan keuangan sebagaimana mestinya. (Soemantri, 2012) dalam penelitiannya menunjukkan hasil bahwa variabel literasi keuangan dapat mempengaruhi kinerja UMKM. Hasil penelitian ini sesuai dengan financial knowledge theory dimana pengetahuan keuangan berkaitan dengan kemampuan seseorang untuk memahami, menganalisis dan mengelola keuangan yang tersedia bagi dirinya untuk menghasilkan keputusan keuangan dengan tepat, dan dapat membantu perkembangan kinerja UMKM. Sehingga, literasi keuangan dianggap sebagai hal yang sangat penting bagi perkembangan kinerja suatu usaha, khususnya UMKM. 


\section{METODE PENELITIAN}

Penelitian ini akan menganalisa pemahaman tentang digitalisasi legalitas dan akuntansi UMKM di Kec.Talang Kelapa. Analisis yang dipakai adalah penelitian deskriptif digunakan untuk memecahkan sekaligus menjawab permasalahan yang terjadi pada masa sekarang, dengan menempuh lengkah-langkah pengumpulan, klasifikasi dan analisis atau pengolahan data, membuat kesimpulan dan laporan dengan tujuan utama untuk membuat penggambaran tentang suatu keadaan secara objective dengan suatu deskripsi (Muhammad, 1982). Penelitian ini menggunakan metode analisis deskriptif dengan pendekatan kuantitatif, dimana menurut (Soejono et al., 2020). Pendekatan kuantitatif menggunakan perhitungan ilmiah yang diperoleh melalui sampel individu dalam suatu objek penelitian dengan memintanya memberikan jawaban pada sebuah survei. Pendapat responden diukur menggunakan skala likert lima skor. Skor 5 untuk pendapat sangat setuju (SS), skor 4 untuk pendapat setuju (S), skor 3 untuk pendapat kurang setuju (KS), skor 2 untuk pendapat tidak setuju (TS), dan skor 1 untuk pendapat sangat tidak setuju (STS). Penelitian menggunakan teknik sampling yaitu simple random sampling dengan objek penelitian adalah 50 pelaku UMKM di Kec.Talang Kelapa Kab Banyuasin.

Jenis data yang akan diteliti adalah data primer ang dperoleh dengan metode penyebaran pertanyaan melalui dokumentasi dan wawancara, sedangkan sumber data adalah 50 puluh orang pelaku UMKM Kec. Talang Kelapa.

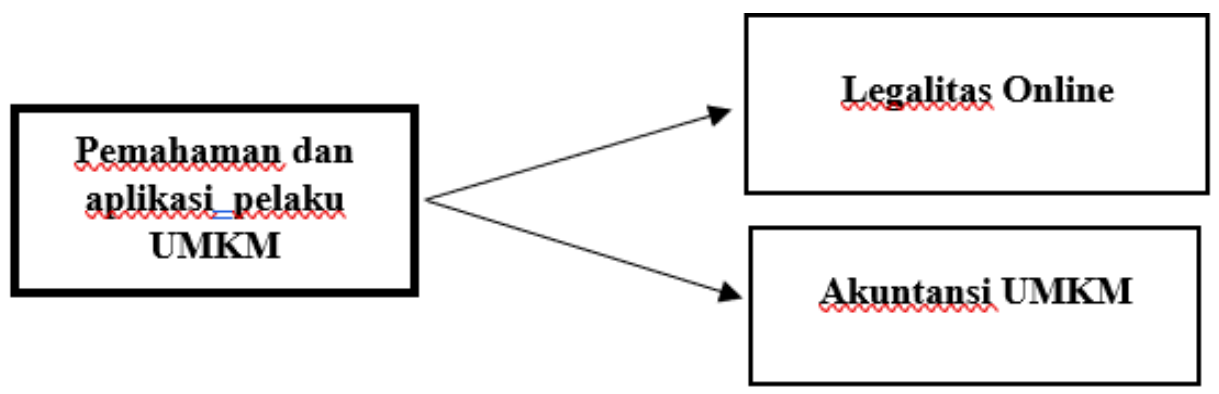

Gambar 1. Desain Penelitian Legalitas Online dan Literasi Akuntansi Terhadap Pemahaman dan Aplikasi UMKM

Desain penelitian ini adalah untuk mengetahui pemahaman dan aplikasi pelaku UMKM tentang Legalitas Online dan Akuntansi untuk UMKM.

\section{HASIL DAN PEMBAHASAN}

Tabel 1. Pentingnya Legalitas Usaha

\begin{tabular}{|c|c|c|c|c|}
\hline $\begin{array}{c}\text { Sangat } \\
\text { Setuju }\end{array}$ & Setuju & $\begin{array}{c}\text { Cukup } \\
\text { Setuju }\end{array}$ & $\begin{array}{c}\text { Tidak } \\
\text { Setuju }\end{array}$ & $\begin{array}{c}\text { Sangat } \\
\text { Tidak Setuju }\end{array}$ \\
\hline $\mathbf{0 , 6 0}$ & 0,24 & 0,16 & 0,00 & 0,00 \\
\hline
\end{tabular}

Hasil perhitungan dengan skala likert menunjukkan bahwa pelaku UMKM mengakui legalitas usaha sangat penting. Sebanyak 60 persen menyatakan sangat setuju bahwa legalitas usaha itu penting. Dari data tabel 2, sebanyak 46 persen menjawab cukup setuju bahwa usaha mereka telah memiliki legalitas usaha. Dan sebanyak 20 persen menjawab sangat setuju, sedangkan 32 persen setuju. Dan hanya 2 persen dari pelaku UMKM yang belum memiliki legalitas usaha. 


\begin{tabular}{|c|ccc|c|}
\hline & \multicolumn{4}{c}{ Tabel 2. Jumlah Usaha yang Memiliki Legalitas } \\
$\begin{array}{c}\text { Sangat } \\
\text { Setuju }\end{array}$ & Setuju & $\begin{array}{c}\text { Cukup } \\
\text { Setuju }\end{array}$ & $\begin{array}{c}\text { Tidak } \\
\text { Setuju }\end{array}$ & $\begin{array}{c}\text { Sangat } \\
\text { Tidak } \\
\text { Setuju }\end{array}$ \\
\hline $\mathbf{0 , 2 0}$ & 0,32 & 0,46 & 0,00 & 0,02 \\
\hline
\end{tabular}

Jumlah legalitas usaha yang diurus oleh pelaku UMKM dapat dilihat pada tabel 3.

Tabel 3. Jumlah Legalitas Usaha yang Diurus Secara Online

\begin{tabular}{|c|c|c|c|c|}
\hline $\begin{array}{c}\text { Sangat } \\
\text { Setuju }\end{array}$ & Setuju & $\begin{array}{c}\text { Cukup } \\
\text { Setuju }\end{array}$ & $\begin{array}{c}\text { Tidak } \\
\text { Setuju }\end{array}$ & $\begin{array}{c}\text { Sangat Tidak } \\
\text { Setuju }\end{array}$ \\
\hline $\mathbf{0 , 4 4}$ & 0,18 & 0,34 & 0,02 & 0,02 \\
\hline
\end{tabular}

Data pada tabel 3 sebanyak 44 persen pelaku UMKM mengurus legalitas usahanya secara online. Hal ini menggambarkan bahwa pelaku usaha sudah menyadari pengurusan legalitas usaha secara online adalah penting

Tabel 4. Jumlah Pelaku Usaha yang Memahami Pengurusan Legalitas Usaha secara Online

\begin{tabular}{|c|cccc|}
$\begin{array}{c}\text { Sangat } \\
\text { Setuju }\end{array}$ & Setuju & $\begin{array}{c}\text { Cukup } \\
\text { Setuju }\end{array}$ & $\begin{array}{c}\text { Tidak } \\
\text { Setuju }\end{array}$ & $\begin{array}{c}\text { Sangat } \\
\text { Tidak } \\
\text { Setuju }\end{array}$ \\
\hline $\mathbf{0 , 2 4}$ & 0,12 & 0,56 & 0,08 & 0,00 \\
\hline
\end{tabular}

Pada tabel 4 sebanyak 56 persen pelaku usaha cukup memahami pengurusan legalitas usaha secara online. Dan yang sangat memahami pengurusannya sebanyak 24 persen. Sebanyak 12 persen yang memahami pengurusan secara online. Dan tidak ada pelaku usaha yang tidak memahami pengurusan legaitas usaha secara online.

Tabel 5. Pentingnya Pengurusan Legalitas Usaha Secara Online di Masa Pandemi

\begin{tabular}{|c|c|c|c|c|}
\hline $\begin{array}{l}\text { Sangat } \\
\text { Setuju }\end{array}$ & Setuju & $\begin{array}{l}\text { Cukup } \\
\text { Setuju }\end{array}$ & $\begin{array}{l}\text { Tidak } \\
\text { Setuju }\end{array}$ & $\begin{array}{l}\text { Sangat } \\
\text { Tidak } \\
\text { Setuju }\end{array}$ \\
\hline $\mathbf{0 , 5 0}$ & 0,14 & 0,32 & 0,02 & 0,02 \\
\hline
\end{tabular}

Berdasarkan tabel 5, sebanyak 50 persen yang sangat setuju pada saat pandemi pengurusan legalitas usaha diurus secara online. Yang tidak setuju penguurusan secara online sebesar 4 persen

Tabel 6. Pentingnya Sosialisasi Legalitas Secara Online

\begin{tabular}{|c|c|c|c|c|}
\hline $\begin{array}{l}\text { Sangat } \\
\text { Setuju }\end{array}$ & Setuju & $\begin{array}{l}\text { Cukup } \\
\text { Setuju }\end{array}$ & $\begin{array}{l}\text { Tidak } \\
\text { Setujuu }\end{array}$ & $\begin{array}{l}\text { Sangat } \\
\text { Tidak } \\
\text { Setuju }\end{array}$ \\
\hline $\mathbf{0 , 5 4}$ & 0,08 & 0,36 & 0,02 & 0,00 \\
\hline
\end{tabular}

Dari data pada tabel 6, dapat dilihat bahwa sosialisasi legalitas secara online sangat penting karena sebanyak 54 persen pelaku umkm sangat setuju diadakannya kegiatan sosialisasi secara online.

Tabel 7. Pentingnya Pembukuan dalam Menjalankan Usaha

\begin{tabular}{|c|c|c|c|c|}
\hline $\begin{array}{l}\text { Sangat } \\
\text { Setuju }\end{array}$ & Setuju & $\begin{array}{l}\text { Cukup } \\
\text { Setuju }\end{array}$ & $\begin{array}{l}\text { Tidak } \\
\text { Setuju }\end{array}$ & $\begin{array}{l}\text { Sangat } \\
\text { Tidak } \\
\text { Setuju }\end{array}$ \\
\hline
\end{tabular}




\begin{tabular}{l|l|l|l|l|}
$\mathbf{0 , 3 8}$ & 0,32 & 0,28 & 0,00 & 0,02 \\
\hline
\end{tabular}

Para pelaku usaha mengakui bahwa kegiatan pembukuaan adalah hal yang penting dalam menjalankan usaha, seperti yang disajikan pada tabel 7.

Tabel 8. Pentingnya Membedakan Keuangan Usaha Dengan Keuangan Pribadi

\begin{tabular}{|c|cccc|}
$\begin{array}{c}\text { Sangat } \\
\text { Setuju }\end{array}$ & Setuju & $\begin{array}{c}\text { Cukup } \\
\text { Setuju }\end{array}$ & $\begin{array}{c}\text { Tidak } \\
\text { Setuju }\end{array}$ & $\begin{array}{c}\text { Sangat } \\
\text { Tidak } \\
\text { Setuju }\end{array}$ \\
\hline $\mathbf{0 , 3 4}$ & 0,40 & 0,26 & 0,00 & 0,00 \\
\hline
\end{tabular}

Pada tabel 8 disajikan bahwa pelaku umkm membedakan keuangan usaha dengan keuangan pribadi.

Tabel 9. Pentingnya Pembukuan Standar

\begin{tabular}{|c|c|c|c|c|}
$\begin{array}{c}\text { Sangat } \\
\text { Setuju }\end{array}$ & Setuju & $\begin{array}{c}\text { Cukup } \\
\text { Setuju }\end{array}$ & $\begin{array}{c}\text { Tidak } \\
\text { Setuju }\end{array}$ & $\begin{array}{c}\text { Sangat } \\
\text { Tidak } \\
\text { Setuju }\end{array}$ \\
\hline $\mathbf{0 , 2 4}$ & 0,44 & 0,30 & 0,00 & 0,02 \\
\hline
\end{tabular}

Pada tabel 9, pelaku umkm sebagian besar sudah menggunakan pembukuaan standar dalam menjalankan usahanya. Mereka sudah menyadari bahwa pembukuan standar penting untuk mengelola usaha.Dalam perhitungan biaya produksi, pelaku usaha sudah cukup memahami proses perhitungan tersebut secara lengkap. Sebagian besar sudah melaksananakan proses perhitungan biaya produksi dalam kegiatan usahanya, seperti yang ditampilkan pada tabel 10 .

Tabel 10. Pentingnya Pemahaman Perhitungan Biaya produksi

\begin{tabular}{|c|cccc|}
\hline $\begin{array}{c}\text { Sangat } \\
\text { Setuju }\end{array}$ & Setuju & $\begin{array}{c}\text { Cukup } \\
\text { Setuju }\end{array}$ & $\begin{array}{c}\text { Tidak } \\
\text { Setuju }\end{array}$ & $\begin{array}{c}\text { Sangat } \\
\text { Tidak } \\
\text { Setuju }\end{array}$ \\
\hline $\mathbf{0 , 3 0}$ & 0,26 & 0,42 & 0,00 & 0,02 \\
\hline
\end{tabular}

Di tabel 11 ditampilkan bahwa pelaku usaha sebagian besar melakukan pencatatan pembukuannya secara manual.

Tabel 11. Pencatatan Pembukuan Secara Manual

\begin{tabular}{|c|c|c|c|c|}
\hline $\begin{array}{l}\text { Sangat } \\
\text { Setuju }\end{array}$ & Setuju & $\begin{array}{l}\text { Cukup } \\
\text { Setuju }\end{array}$ & $\begin{array}{l}\text { Tidak } \\
\text { Setuju }\end{array}$ & $\begin{array}{c}\text { Sangat } \\
\text { Tidak Setuju }\end{array}$ \\
\hline 0,50 & 0,12 & 0,34 & 0,04 & 0,00 \\
\hline
\end{tabular}

Pelaku umkm juga sudah menggunakan pencatatan pembukuan dengan software. Ada 98 persen yang melakukan pembukuan menggunakan sofware. Mereka setuju jika pencatatannya menggunakan sofware, seperti yang bisa dilihat pada tabel 12 .

Tabel 12Pencatatan Pembukuan Menggunakan Software

\begin{tabular}{|c|cccc|}
\hline $\begin{array}{c}\text { Sangat } \\
\text { Setuju }\end{array}$ & Setuju & $\begin{array}{c}\text { Cukup } \\
\text { Setuju }\end{array}$ & $\begin{array}{c}\text { Tidak } \\
\text { Setuju }\end{array}$ & $\begin{array}{c}\text { Sangat } \\
\text { Tidak } \\
\text { Setuju }\end{array}$ \\
\hline $\mathbf{0 , 2 4}$ & 0,10 & 0,64 & 0,02 & 0,00 \\
\hline
\end{tabular}

Masih ada pelaku umkm yang belum mengenal pembukuan dengan sofware secara baik sehingga mereka memilih mengerjakan pembukuan secara manual. Seperti yang disajikan pada tabel 13. 
Tabel 13. Jumlah Pelaku UMKM yang Belum Mengenal Aplikasi Pembukuan

\begin{tabular}{|c|ccc|c|}
\hline $\begin{array}{c}\text { Sangat } \\
\text { Setuju }\end{array}$ & Setuju & $\begin{array}{c}\text { Cukup } \\
\text { Setuju }\end{array}$ & $\begin{array}{c}\text { Tidak } \\
\text { Setuju }\end{array}$ & $\begin{array}{c}\text { Sangat } \\
\text { Tidak } \\
\text { Setuju }\end{array}$ \\
\hline $\mathbf{0 , 0 8}$ & 0,08 & 0,76 & 0,08 & 0,00 \\
\hline
\end{tabular}

Tabel 14Jumlah Pelaku UMKM yang Telah Mengenal Aplikasi Pembukuan

\begin{tabular}{|c|c|ccc|}
\hline $\begin{array}{c}\text { Sangat } \\
\text { Setuju }\end{array}$ & Setuju & $\begin{array}{c}\text { Cukup } \\
\text { Setuju }\end{array}$ & $\begin{array}{c}\text { Tidak } \\
\text { Setuju }\end{array}$ & $\begin{array}{c}\text { Sangat } \\
\text { Tidak } \\
\text { Setuju }\end{array}$ \\
\hline $\mathbf{0 , 1 4}$ & 0,16 & 0,60 & 0,10 & 0,00 \\
\hline
\end{tabular}

Pada tabel 14, pelaku sudah mengenal dan memahami dengan baik penggunaan aplikasi pembukuaan dengan software. Sehingga mereka memilih untuk menggunakan aplikasi tersebut dalam membuat pembukuan. Di era digital dengan perkembangan teknologi yang cukup pesat. Maka pelaku umkm diharuskan untuk dapat mengikuti dan menggunakan teknologi tersebut. Sehingga mereka butuh sosialisasi cara penggunaan teknologi. Terutama sosialisasi pembukuan secara digital.

Tabel 15. Jumlah UMKM yang Membutuhkan Sosialisasi Pembukuan Secara Digital

\begin{tabular}{|c|c|c|c|c|}
$\begin{array}{c}\text { Sangat } \\
\text { Setuju }\end{array}$ & Setuju & $\begin{array}{c}\text { Cukup } \\
\text { Setuju }\end{array}$ & $\begin{array}{c}\text { Tidak } \\
\text { Setuju }\end{array}$ & $\begin{array}{c}\text { Sangat } \\
\text { Tidak Setuju }\end{array}$ \\
\hline $\mathbf{0 , 4 2}$ & 0,14 & 0,42 & 0,02 & 0,00 \\
\hline
\end{tabular}

Dapat dilihat pada tabel 15, sebanyak 98 persen pelaku umkm membutuhkan sosialisasi pembukuan secara digital.

\section{KESIMPULAN}

Berdasarkan hasil dan pembahasan di atas dalam digitalisasi legalitas yang dilakukan pada UMKM dalam penelitian ini bisa diakui bahwa legalitas usaha sangat penting hampir 60 persen responden mengakui sangat setuju dalam kelegalitasan pada usaha. Sebanyak 60 persen juga pelaku UMKM yang cukup setuju dan telah mengenal aplikasi pembukuan, 14 persen yang mengakui sangat setuju. Hal ini bisa didikatakan bahwa hampir seluruh pelaku UMKM telah mengikuti perkembangan teknologi yang sangat pesat sekarang dan juga bisa di katakan bahwa sistem OSS dapat digunakan dalam menemukan solusi legalitas bagi UMKM.

\section{Acknowledgements}

Terima kasih kepada Bapak Camat dan UMKM di Kec. Talangkelapa kab.Banyuasin atas support data yang dapat mendukung kelancaran penulisan artikel ini

\section{DAFTAR PUSTAKA}

Agustin, C. D., Msi, D. C., Fitriyah, E., \& Ak, S. E. M. S. A. (n.d.). UMKM( Studi Kasus Pada Usaha, Mikro, Kecil dan Menengah di Kecamatan.

Arrum, D. A. (2019). Kepastian Hukum Dalam Perizinan Berusaha Terintegrasi Secara Elektronik (Online Single Submission) di Indonesia. Jurist-Diction, 2(5), 1631. https://doi.org/10.20473/jd.v2i5.15222 
Gultom, A. W. (2020). Pelatihan Kewirausahaan Pembuatan Izin Usaha Melalui Sistem Online Single Submission (OSS) Bagi UMKM di Sumatera Selatan. Dharma Raflesia : Jurnal Ilmiah Pengembangan Dan Penerapan IPTEKS, 18(2), 150-159. https://doi.org/10.33369/dr.v18i2.13478

Hudha, C. (2017). Pengaruh Tingkat Pendidikan, Pengetahuan Akuntansi Dan Pelatihan Akuntansi Terhadap Penggunaan Informasi Akuntansi Dimoderasi Ketidakpastian Lingkungan Usaha Kecil Menengah. Jurnal Ekonomi Pendidikan Dan Kewirausahaan, 5(1), 68. https://doi.org/10.26740/jepk.v5n1.p68-90

Muhammad, A. (1982). Penelitian Pendidikan, Prosedur dan Strategi. Angkasa.

Pramanik, N. D. (2020). Dampak Bantuan Paket Sembako Dan Bantuan Langsung Tunai Terhadap Kelangsungan Hidup Masyarakat Padalarang Pada Masa Pandemi Covid 19. Jurnal Ekonomi, Sosial Dan Humaniora, 01(12), 113-120. https://www.jurnalintelektiva.com/index.php/jurnal/article/view/209/149

Rofiah, C. (2020). Implementasi Technology Readiness Usaha Mikro Kecil Menengah Di Era Revolusi Industri 4.0 (Studi Pada Komunitas Perhimpunan Makanan Minuman Kabupaten Jombang). Develop, 4(2), 103. https://doi.org/10.25139/dev.v4i2.2916

Soejono, F., Sunarni, T., Bendi, R. K. J., Efila, M. R., Anthony, S., \& Angeliana, W. (2020). Pendampingan Usaha: Penggunaan One Single Submission untuk Ijin Usaha. Wikrama Parahita : Jurnal Pengabdian Masyarakat, 4(2), 103-108. https://doi.org/10.30656/jpmwp.v4i2.2214

Soemantri. (2012). Digitalisasi Usaha Mikro, Kecil dan Menengah. November, 2.

Suhardiyah, M., Ulfa Puspa Wanti Widodo, \& Yurida Sasmita. (2020). Legalisasi Dan Pengelolaan Usaha Pada UMKM. Ekobis Abdimas : Jurnal Pengabdian Masyarakat, 1(1), 45-53. https://doi.org/10.36456/ekobisabdimas.1.1.45-53.2340

Thaha, A. F. (2020). Dampak Covid-19 Terhadap UMKM di Indonesia. Jurnal Brand, 2(1), $147-153$.

UU No. 20 Tahun 2008. (2008). UU No. 20 Tahun 2008. UU No. 20 Tahun 2008, 1, 1-31.

Yohanna, L., Rorin Insana, D. M., \& Sondari, E. (2016). Upaya Peningkatan Usaha Masyarakat Melalui Pengurusan Perizinan Usaha Dan Merek. Jurnal Surya : Seri Pengabdian Kepada Masyarakat, 2, 73-78. www.pustakadunia.com 